\title{
Pelatihan Pembuatan dan Pendampingan Penerapan Media Pembelajaran Berbasis ICT Menggunakan Lectora Inspire Bagi Guru Sekolah Dasar Di Kabupaten Kuningan
}

\author{
Nana Sutarna ${ }^{1}$, Dedi Iskandar ${ }^{2}$, Nika Cahyati ${ }^{3}$, Ahmad Fajri Lutfi $^{4}$ \\ STKIP Muhammadiyah Kuningan \\ E-mail: nana@upmk.ac.id¹, ahmadfajrilutfi@upmk.ac.id², nika@upmk.ac.id³ ${ }^{3}$ naufaladzaky1@upmk.ac.id².
}

\begin{abstract}
Abstrak
Tujuan pelaksanaan program kemitraan masyarakat berupa pelatihan ini adalah untuk meningkatkan kompetensi guru di Indonesia menciptakan, mengembangkan dan mengimplementasikan media pembelajaran berbasis ICT menggunakan Lectora Inspire. Pelatihan ini dilaksanakan pada guru sekolah dasar yang berada di Kecamatan Japara Kabupaten Kuningan. Persoalan pembelajaran pada mitra adalah guru jarang menggunakan media pembelajaran yang interaktif saat pembelajaran di kelas. Hal tersebut membuat motivasi peserta didik cenderung rendah. Padahal sebagaimana diketahui bahwa tuntutan kurikulum 2013 dan pesatnya IPTEKS mengharuskan guru kreatif menggunakan media pembelajaran berbasis ICT. Potensi guru-guru sekolah dasar di kecamatan Japara cukup besar dan keberadaan perangkat teknologi di sekolah cukup memadai namun dari segi kompetensi perlu terus ditingkatkan. Kompetensi tersebut salah satunya adalah kemampuan pembuatan media pembelajaran menggunakan ICT yang masih sangat minim. Hal ini dikarenakan belum adanya kegiatan pelatihan khusus pembuatan media pembelajaran berbasis ICT. Solusi dari permasalahan tersebut adalah dilaksanakannya pelatihan pembuatan media pembelajaran berbasis ICT menggunakan Lectora Inspire. Kegiatan pelatihan ini terdiri dari tahapan sebagai berikut: 1) survey lapangan (mitra); 2) Koordinasi dengan kepala sekolah dan guru; 3) Sosialisasi Program; 4) Pelaksanaan Program; dan 5) Evaluasi kegiatan.
\end{abstract}

Kata kunci: ICT, Lectora Inspire, Media pembelajaran, Pelatihan

\begin{abstract}
The purpose of implementing the community partnership program in the form of this training is to improve teacher competence in Indonesia in creating, developing and implementing ICT-based learning media using Lectora Inspire. This training was held for elementary school teachers in Japara District, Kuningan Regency. The problem of learning with partners is that teachers rarely use interactive learning media when learning in class. This makes students' motivation tends to be low. Yet as it is well known that the demands of the 2013 curriculum and the rapid pace of science and technology require creative teachers to use ICTbased learning media. The potential of elementary school teachers in Japara sub-district is quite large and the existence of technological devices in schools is quite adequate, but in terms of competency, it needs to be continuously improved. One of the competencies is the ability of making learning media using ICT which is still very minimal. This is due to the absence of specific training activities in the manufacture of ICT-based learning media. The solution to these problems is the implementation of training on making ICT-based learning media using Lectora Inspire. The training activities consist of the following stages: 1) field survey (partners); 2) Coordination with school principals and teachers; 3) Program Socialization; 4) Program Implementation; and 5) Evaluation of activities.
\end{abstract}

Keywords: ICT, Lectora Inspire, Learning media, Training. 


\section{PENDAHULUAN}

Perkembangan teknologi informasi dalam era digital yang semakin pesat memberikan tantangan tersendiri bagi semua bidang kehidupan. Hampir keseluruhan aktivitas senantiasa bersentuhan secara langsung dengan perangkat teknologi informasi dan komunikasi. Pasal 3 Undang-Undang Nomor 20 Tahun 2003 tentang Sistem Pendidikan Nasional, menerangkan bahwa pendidikan nasional berfungsi mengembangkan kemampuan dan membentuk watak serta peradaban bangsa yang bermartabat dalam rangka mencerdaskan kehidupan bangsa. Selain itu pendidikan bertujuan untuk mengembangkan potensi peserta didik agar menjadi manusia yang beriman dan bertakwa kepada Tuhan Yang Maha Esa, berakhlak mulia, sehat, berilmu, cakap, kreatif, mandiri, dan menjadi warga negara yang demokratis serta bertanggung jawab (Mendikbud, 2014: 19). Oleh karena itu, salah satu skill yang perlu ditingkatkan oleh guru adalah penggunaan IT sebagai media pembelajaran di kelas.

Sutarna (2019:35) mengatakan bahwa media pembelajaran yang dirancang dengan baik dapat merangsang timbulnya proses atau dialog mental pada diri siswa. Sejalan dengan itu, Rumijan et al (2017) berpendapat bahwa keterampilan pengembangan desain dan pembuatan media pembelajaran yang dimiliki guru akan menghasilkan benda yang dapat digunakan sebagai media pembelajaran yang dapat memungkinkan murid menjadi aktif, kreatif, dan menyenangkan dalam kegiatan belajarnya. Kaitannya dengan ranah IT, Munir (2013: 51) menjelaskan bahwa multimedia mempercayakan pada model pembelajaran Contextual Teaching and Learning (CTL) yang berpusat pada berbagai aspek yang mendukung pembelajaran, lingkungan belajar, kelas, laboratorium, komputer, websites, maupun worksite. Sesuai dengan pendapat tersebut Mayer (2009: 4) menjelaskan bahwa multimedia merujuk pada teknologi untuk menyajikan materi dalam bentuk verbal dan visual. Sedangkan Surjono (2010: 15) menjelaskan bahwa teknologi pembelajaran yang dewasa ini aplikasinya berupa pemanfaatan proses dan produk teknologi informasi dan komunikasi (information and communication technology/ICT) untuk memecahkan masalah-masalah pendidikan dan pembelajaran, memiliki banyak manfaat atau keuntungan.

Pembelajaran dalam Kurikulum 2013 berupaya untuk mengubah pola pembelajaran pasif menjadi pembelajaran aktif mencari dimana siswa aktif membangun pengetahuannya. Sebagian besar sekolah dasar di Kabupaten Kuningan telah menerapkan kurikulum 2013. Salah satu permasalahan yang dihadapi yaitu guru masih sangat awam dengan penggunaan IT.

Berdasarkan hasil wawancara dengan Ketua K3S (Ketua Kelompok Kerja Kepala Sekolah) SD Kecamatan Japara Kabupaten Kuningan yang sudah menerapkan Kurikulum 2013, menjelaskan bahwa guru masih jarang menggunakan IT karena kemampuan guru masih rendah dalam menggunakan IT. Padahal salah satu kompetensi yang wajib dimiliki oleh guru dalam Kurikulum 2013 adalah keterampilan menggunakan IT dalam pembelajaran. Fakta ini memperkuat hasil penelitian yang dilakukan oleh Anwariningsih (2014) mengenai kesiapan penggunaan IT di sekolah, menunjukkan bahwa $70 \%$ guru-guru kelas belum memiliki kemampuan dalam mengoperasikan komputer. Sedangkan $30 \%$ guru sudah mampu mengoperasikan komputer akan tetapi hanya sebatas untuk mengetik saja/keperluan administrasi sekolah. Penelitian lain dilakukan oleh Suradijono (2004) dari studi-studi yang ada, pembelajaran berbasis komputer (courseware) bila dibuat dengan baik terbukti dapat meningkatkan proses belajar pada diri seseorang. Selanjutnya Sanjaya (2010) mengatakan bahwa dengan kemajuan teknologi, guru dapat menggunakan berbagai media sesuai dengan kebutuhan dan tujuan pembelajaran.

Oleh karena itu kegiatan Pengabdian Program Kemitraan Masyarakat (PKM) ini dimaksudkan untuk menyiapkan guru sekolah dasar khususnya yang di Kecamatan Japara Kabupaten Kuningan dalam membuat dan mengimplementasikan media pembelajaran berbasis ICT menggunakan aplikasi Lectora Inspire. Lectora inspire dikembangkan oleh Trivantis Corporation yang merupakan Authoring Tool untuk pengembangan konten e-learning. Pendirinya adalah Timothy D. Loudermilk di Cincinnati, Ohio, Amerika tahun 1999 (Muhammad Mas'ud, 2012:1). Shalikhah (2016:111) mengatakan bahwa lectora inspire merupakan salah satu program aplikasi yang dapat digunakan untuk membuat presentasi maupun media 
pembelajaran. Lectora inspire didesain khusus bagi pemula, sehingga keunggulan dari lectora inspire sangat mudah digunakan dalam pembuatan media pembelajaran dan dapat membuat materi uji atau evaluasi (Shalikhah et al, 2017:13).

Berdasarkan hal tersebut maka dalam PKM ini akan difokuskan pada workshop perencanaan pengenalan media pembelajaran berbasis ICT menggunakan Lectora Inspire, pembuatan dan pengembangan media pembelajaran berbasis ICT dan pendampingan implementasi media pembelajaran. Kegiatan PKM diharapkan mampu membantu guru dalam mengimplementasikan media pembelajaran berbasis ICT.

\section{BAHAN DAN METODE}

Perkembangan teknologi informasi dalam era digital yang semakin pesat memberikan tantangan tersendiri bagi semua bidang kehidupan. Hampir keseluruhan aktivitas senantiasa bersentuhan secara langsung dengan perangkat teknologi informasi dan komunikasi. Pasal 3 Undang-Undang Nomor 20 Tahun 2003 tentang Sistem Pendidikan Nasional, menerangkan bahwa pendidikan nasional berfungsi mengembangkan kemampuan dan membentuk watak serta peradaban bangsa yang bermartabat dalam rangka mencerdaskan kehidupan bangsa. Selain itu pendidikan bertujuan untuk mengembangkan potensi peserta didik agar menjadi manusia yang beriman dan bertakwa kepada Tuhan Yang Maha Esa, berakhlak mulia, sehat, berilmu, cakap, kreatif, mandiri, dan menjadi warga negara yang demokratis serta bertanggung jawab (Mendikbud, 2014: 19). Oleh karena itu, salah satu skill yang perlu ditingkatkan oleh guru adalah penggunaan IT sebagai media pembelajaran di kelas.

Sutarna (2019:35) mengatakan bahwa media pembelajaran yang dirancang dengan baik dapat merangsang timbulnya proses atau dialog mental pada diri siswa. Sejalan dengan itu, Rumijan et al (2017) berpendapat bahwa keterampilan pengembangan desain dan pembuatan media pembelajaran yang dimiliki guru akan menghasilkan benda yang dapat digunakan sebagai media pembelajaran yang dapat memungkinkan murid menjadi aktif, kreatif, dan menyenangkan dalam kegiatan belajarnya. Kaitannya dengan ranah IT, Munir (2013: 51) menjelaskan bahwa multimedia mempercayakan pada model pembelajaran Contextual Teaching and Learning (CTL) yang berpusat pada berbagai aspek yang mendukung pembelajaran, lingkungan belajar, kelas, laboratorium, komputer, websites, maupun worksite. Sesuai dengan pendapat tersebut Mayer (2009: 4) menjelaskan bahwa multimedia merujuk pada teknologi untuk menyajikan materi dalam bentuk verbal dan visual. Sedangkan Surjono (2010: 15) menjelaskan bahwa teknologi pembelajaran yang dewasa ini aplikasinya berupa pemanfaatan proses dan produk teknologi informasi dan komunikasi (information and communication technology/(CT) untuk memecahkan masalah-masalah pendidikan dan pembelajaran, memiliki banyak manfaat atau keuntungan.

Pembelajaran dalam Kurikulum 2013 berupaya untuk mengubah pola pembelajaran pasif menjadi pembelajaran aktif mencari dimana siswa aktif membangun pengetahuannya. Sebagian besar sekolah dasar di Kabupaten Kuningan telah menerapkan kurikulum 2013. Salah satu permasalahan yang dihadapi yaitu guru masih sangat awam dengan penggunaan IT.

Berdasarkan hasil wawancara dengan Ketua K3S (Ketua Kelompok Kerja Kepala Sekolah) SD Kecamatan Japara Kabupaten Kuningan yang sudah menerapkan Kurikulum 2013, menjelaskan bahwa guru masih jarang menggunakan IT karena kemampuan guru masih rendah dalam menggunakan IT. Padahal salah satu kompetensi yang wajib dimiliki oleh guru dalam Kurikulum 2013 adalah keterampilan menggunakan IT dalam pembelajaran. Fakta ini memperkuat hasil penelitian yang dilakukan oleh Anwariningsih (2014) mengenai kesiapan penggunaan IT di sekolah, menunjukkan bahwa $70 \%$ guru-guru kelas belum memiliki kemampuan dalam mengoperasikan komputer. Sedangkan $30 \%$ guru sudah mampu mengoperasikan komputer akan tetapi hanya sebatas untuk mengetik saja/keperluan administrasi sekolah. Penelitian lain dilakukan oleh Suradijono (2004) dari studi-studi yang ada, pembelajaran berbasis komputer (courseware) bila dibuat dengan baik terbukti dapat meningkatkan proses belajar pada diri seseorang. Selanjutnya Sanjaya (2010) mengatakan bahwa dengan kemajuan teknologi, guru dapat menggunakan berbagai media sesuai dengan kebutuhan dan tujuan pembelajaran. 
Oleh karena itu kegiatan Pengabdian Program Kemitraan Masyarakat (PKM) ini dimaksudkan untuk menyiapkan guru sekolah dasar khususnya yang di Kecamatan Japara Kabupaten Kuningan dalam membuat dan mengimplementasikan media pembelajaran berbasis ICT menggunakan aplikasi Lectora Inspire. Lectora inspire dikembangkan oleh Trivantis Corporation yang merupakan Authoring Tool untuk pengembangan konten e-learning. Pendirinya adalah Timothy D. Loudermilk di Cincinnati, Ohio, Amerika tahun 1999 (Muhammad Mas'ud, 2012:1). Shalikhah (2016:111) mengatakan bahwa lectora inspire merupakan salah satu program aplikasi yang dapat digunakan untuk membuat presentasi maupun media pembelajaran. Lectora inspire didesain khusus bagi pemula, sehingga keunggulan dari lectora inspire sangat mudah digunakan dalam pembuatan media pembelajaran dan dapat membuat materi uji atau evaluasi (Shalikhah et al, 2017:13).

Berdasarkan hal tersebut maka dalam PKM ini akan difokuskan pada workshop perencanaan pengenalan media pembelajaran berbasis ICT menggunakan Lectora Inspire, pembuatan dan pengembangan media pembelajaran berbasis ICT dan pendampingan implementasi media pembelajaran. Kegiatan PKM diharapkan mampu membantu guru dalam mengimplementasikan media pembelajaran berbasis ICT.

\section{METODE PELAKSANAAN}

Kegiatan pengabdian masyarakat ini dilakukan dengan metode pelatihan. Metode yang digunakan dalam kegiatan ini adalah Model B (Pendampingan) dan metode pelaksanaan kegiatan ini metoda II (Pendampingan), yaitu: pelatihan dalam bentuk penyajian materi pelatihan dan penugasan untuk bentuk membuat media (Sriyanti et al, 2015). Evaluasi dilakukan pada akhir kegiatan berupa angket. Indikator pencapaian tujuan apabila sekurang-kurangnya $80 \%$ dari khalayak sasaran dapat melaksanakannya.

Peserta kegiatan dalam program pengabdian ini adalah guru-guru sekolah dasar yang berasal dari seluruh SD di Kecamatan Japara Kabupaten Kuningan yang berjumlah 43 orang guru. Kegiatan pengabdian ini dilaksanakan di Aula UPTD Pendidikan Japara yang beralamat di Jalan Raya Desa Japara (Samping SDN 2 Japara) RT/RW 08/04 Kecamatan Japara Kabupaten Kuningan.

PKM ini terdiri dari dua kegiatan yakni pelatihan pembuatan dan pendampingan penerapan, oleh karenanya ada beberapa tahapan dalam pelaksanaannya yakni: (1) survey lapangan (mitra); (2) Koordinasi dengan kepala sekolah dan guru; (3) Sosialisasi Program; (4) Pelaksanaan Program; dan (5) Evaluasi kegiatan.

Alur pelaksanaan kegiatan pelatihan pembuatan dan pendampingan penerapan media pembelajaran berbasis ICT menggunakan Lectora Inspire bagi guru sekolah dasar di Kecamatan Japara Kabupaten Kuningan adalah sebagai berikut.

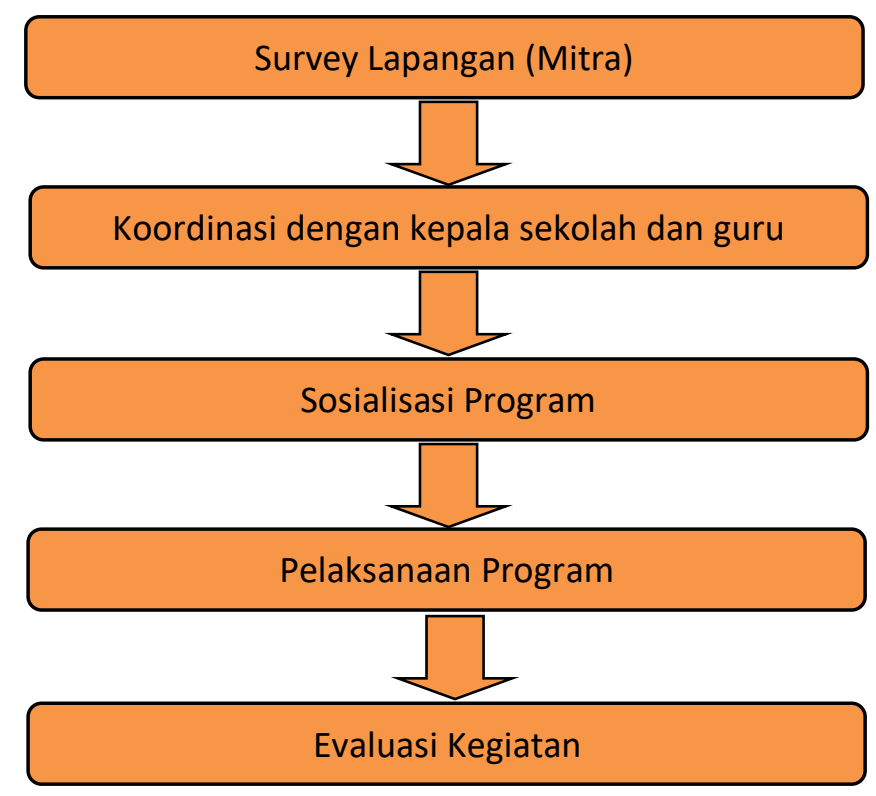


Berikut ini merupakan penjabaran kegiatan tim pengabdi dan guru SDN se-Kecamatan Japara sebagai peserta pengabdian berdasarkan alur pelaksanaan pengabdian pelatihan pembuatan dan pendampingan penerapan media pembelajaran berbasis ICT menggunakan Lectora Inspire bagi guru sekolah dasar.

\section{Survey Lapangan (Mitra)}

Survei lapangan dilakukan oleh tim pengabdi bertujuan untuk mengamati situasi dan keadaan sekolah yang direncanakan sebagai objek sasaran. Kegiatan pengabdian masyarakat ini dilaksanakan di Aula UPTD Pendidikan Japara di Kabupaten Kuningan. Mitra yang terlibat yaitu seluruh sekolah dasar di Kecamatan Japara Kabupaten Kuningan melalui UPTD Dinas Pendidikan Japara dan Ketua K3S SD Kecamatan Japara. Mitra berkontribusi mengarahkan guru yang akan mengikuti pelatihan, memfasilitasi pembelajaran dengan menggunakan media pembelajaran berbasis ICT, ikut melakukan monitoring dan evaluasi penggunaan media yang dibuat guru. Survey lapangan ini dilaksanakan pertengahan februari sampai bulan maret 2019.

\section{Koordinasi dengan Kepala Sekolah dan Guru}

Sebelum tahapan ini dilaksanakan, tim pengabdi terlebih dahulu melakukan perizinan kepada Kepala Dinas Pendidikan dan Kebudayaan Kabupaten Kuningan berupa rekomendasi kegiatan pelatihan pembuatan dan pendampingan penerapan media pembelajaran berbasis ICT menggunakan Lectora Inspire bagi guru sekolah dasar di Kecamatan Japara.

Berkoordinasi dengan guru dan kepala sekolah untuk menentukan kesepakatan mufakat dalam pelaksanaan pembuatan dan pendampingan penerapan media pembelajaran berbasis ICT bagi Guru Sekolah Dasar di Kecamatan Japara Kabupaten Kuningan. Rangkaian kegiatan ini dilaksanakan pada akhir bulan Maret sampai bulan Mei 2019.

\section{Sosialisasi Program}

Sosialisasi program bertujuan untuk memberi informasi tentang rencana serangkaian pelaksanaan program. Sosialisasi disampaikan kepada seluruh Sekolah Dasar di Kecamatan Japara Kabupaten Kuningan yang guru-gurunya akan mendapat pelatihan. Tahap sosialisasi ini dilaksanakan massif baik melalui surat cetak maupun informasi sosial media (whatsapp) berkoordinasi dengan Kepala UPTD Pendidikan Japara dan Ketua K3S SD Kecamatan Japara. Kegiatan sosialisasi ini dilaksanakan pada bulan Juni dan pertengahan Juli 2019.

\section{Pelaksanaan Program}

Workshop Pengenalan Media Pembelajaran Berbasis ICT menggunakan Lectora Inspire

Tugas dari tim pengabdi adalah mempersiapkan kegiatan yang dilakukan di Aula UPTD Pendidikan Japara diawali dengan proses sosialisasi program pengabdian. Kemudian dilanjutkan dengan pemberian materi tentang media pembelajaran berbasis ICT menggunakan Lectora Inspire. Setelah pemberian materi, peserta diminta untuk melakukan analisis kebutuhan, meliputi analisis karakteristik siswa, analisis implementasi kurikulum yang dilaksanakan, analisis materi, ketersediaan bahan, kesediaan sarana dan prasarana penunjang pembelajaran berbasis komputer yang dimiliki oleh guru maupun sekolah. Workshop ini terdiri dari beberapa sesi penyajian materi yang disampaikan oleh tim pengabdi sebagai narasumber utama dan beberapa narasumber lain sebagai pendukung.

Tugas dari guru-guru sekolah dasar sebagai peserta pelatihan adalah menghadiri acara workshop yang dilaksanakan di Aula UPTD Pendidikan Japara diawali dengan proses sosialisasi program pengabdian dan dilanjutkan dengan materi tentang pengembangan media pembelajaran berbasis ICT. Adapun materi yang harus dipahami adalah mengenai pembuatan media pembelajaran berbasis ICT di sekolah dasar serta pentingnya penggunaannya dalam proses pembelajaran. Model pembelajaran berbasis ICT yang dimaksud menggunakan aplikasi Lectora Inspire yang disosialisasikan adalah title wizard 'Aqua'. Pada akhir kegiatan diharapkan peserta mampu menentukan materi yang akan dipilih untuk diimplementasikan pada media pembelajaran ICT menggunakan Lectora Inspire.

Pembuatan dan Pengembangan Media Pembelajaran Berbasis ICT menggunakan Lectora Inspire 
Tugas dari tim pengabdi adalah menyediakan modul pelatihan, membimbing pembuatan dan pengembangan media pembelajaran berbasis ICT menggunakan Lectora Inspire dengan menggunakan title wizard 'Aqua'.

Dengan didampingi oleh tim pendamping, guru membuat dan mengembangkan media pembelajaran berbasis ICT menggunakan Lectora Inspire dengan menggunakan title wizard 'Aqua' sesuai dengan materi yang dipilih oleh guru berdasarkan hasil analisis sebelumnya. Pendampingan Penerapan Media Pembelajaran Berbasis ICT menggunakan Lectora Inspire Media pembelajaran yang telah dibuat diimplementasikan pada pembelajaran di kelas pada masing-masing sekolah. Saat pembelajaran, guru didampingi oleh tim pengabdian. Akhir pembelajaran, tim pengabdian dan guru mengevaluasi bersama-sama terhadap efektivitas media pembelajaran berbasis ICT menggunakan Lectora Inspire.

\section{Evaluasi Kegiatan}

Mengevaluasi pelaksanaan pembuatan dan penerapan media pembelajaran berbasis ICT menggunakan Lectora Inspire yang dilaksanakan oleh guru, memberikan saran untuk mengembangkan media pembelajaran berbasis ICT sesuai dengan kebutuhan masing-masing kelas.

\section{HASIL DAN PEMBAHASAN}

Pelaksanaan kegiatan pengabdian yang dilakukan oleh tim dosen dari program studi PGSD dan program studi pendidikan teknologi dan ilmu komunikasi selama kurang lebih 2 bulan, dari bulan Juli 2019 hingga Agustus 2019. Program pengabdian ini terbagi menjadi 7 sesi, dengan kegiatan masing-masing sesi sebagai berikut:

\section{Sesi 1}

Sesi 1 dilaksanakan pada hari senin, 22 Juli 2019 bertempat di Aula UPTD pendidikan Japara. Sesi ini merupakan pembukaan kegiatan PKM yang juga dihadiri oleh Kepala Dinas Pendidikan dan Kebudayaan Kabupaten Kuningan, Kepala UPTD Pendidikan Japara, Ketua K3S SD Kecamatan Japara, unsur PGRI dan tamu undangan lainnya. Tiga materi inti yang disajikan pada sesi ini yakni: (1) Kebijakan Pendidikan pada Era Revolusi Industri 4.0; (2) Tantangan Guru di Era Revolusi Industri 4.0; dan (3) : Media Pembelajaran di Sekolah Dasar Berbasis ICT menggunakan Lectora Inspire.

\section{Sesi 2}

Sesi 2 dilaksanakan pada hari Sabtu, 27 Juli 2019 bertempat di Aula UPTD pendidikan Japara. Rangkaian kegiatan pada sesi ini adalah instalasi aplikasi Lectora Inspire pada laptop peserta pelatihan sekaligus pengenalan media pembelajaran berbasis ICT menggunakan Lectora Inspire.

\section{Sesi 3}

Sesi 3 dilaksanakan pada hari Senin, 29 Juli 2019 bertempat di Aula UPTD pendidikan Japara. Kegiatan pada sesi ini mengenai tahapan pembuatan media pembelajaran berbasis ICT menggunakan Lectora Inspire yang dipandu oleh tim pengabdi.

\section{Sesi 4}

Sesi 4 dilaksanakan pada hari Sabtu, 3 Agustus 2019 bertempat di Aula UPTD pendidikan Japara. Pada sesi ini peserta pelatihan sudah dibagi materi untuk kemudian dibuatkan media pembelajarannya. Setiap guru diwajibkan membuat satu media yang berasal dari satu subtema pembelajaran sesuai kelas yang dipegangnya.

\section{Sesi 5}

Sesi 5 dilaksanakan pada hari Senin, 5 Agustus 2019 bertempat di Aula UPTD pendidikan Japara. Pada sesi ini peserta kegiatan pelatihan mempresentasikan hasil media pembelajaran yang telah dibuatnya. Fokus presentasi adalah guru-guru yang menjadi wali kelas pada kelas rendah.

Sesi 6

Sesi 6 dilaksanakan pada hari Sabtu, 10 Agustus 2019 bertempat di Aula UPTD pendidikan Japara. Pada sesi ini peserta kegiatan pelatihan mempresentasikan hasil media pembelajaran yang telah dibuatnya. Fokus presentasi adalah guru-guru yang menjadi wali kelas pada kelas tinggi. 


\section{Sesi 7}

Sesi 7 dilaksanakan di dua tempat yakni di SDN Singkup dan SDN Kalimati. Kegiatan pelatihan pada sesi ini adalah pendampingan penerapan media pembelajaran berbasis ICT menggunakan Lectora Inspire pada dua sekolah sampel untuk kelas rendah dan kelas tinggi. Pada sesi ini juga dilakukan evaluasi kegiatan dari awal hingga akhir mengenai pembuatan dan penerapan media pembelajaran ICT menggunakan Lectora Inspire untuk jenjang sekolah dasar.

Beberapa hasil yang telah dicapai dalam Kegiatan Program Kemitraan Masyarakat (PKM) ini adalah sebagai berikut:

1) Meningkatnya pengetahuan dan pemahaman guru berkenaan dengan penggunaan media pembelajaran berbasis ICT menggunakan aplikasi Lectora Inspire. Sebagaimana telah dipaparkan sebelumnya bahwa kegiatan ini bertujuan membekali guru untuk memahami penggunaan media pembelajaran berbasis ICT pada jenjang sekolah dasar.

2) Meningkatnya kemampuan guru dalam membuat media pembelajaran berbasis ICT menggunakan aplikasi Lectora Inspire. Media pembelajaran berbasis ICT menggunakan aplikasi Lectora Inspire dapat digunakan salah satu alternatif variasi pembelajaran sebagai upaya untuk mewujudkan pembelajaran aktif.

3) Selama proses pelatihan $90 \%$ peserta pelatihan memiliki antusiasme yang tinggi untuk ikut serta dalam membuat dan mengembangkan media pembelajaran berbasis ICT menggunakan aplikasi Lectora Inspire. Kendala yang dialami selama pelatihan adalah $10 \%$ peserta belum terbiasa menggunakan media komputer.

4) Pada proses pendampingan penerapan media pembelajaran berbasis ICT menggunakan aplikasi Lectora Inspire siswa terlihat begitu antusias dalam mengikuti pembelajaran. Dari hasil postes setelah pembelajaran,siswa yang dinyatakan tuntas sebesar $90 \%$ siswa.

5) Dari hasil evaluasi yang dilakukan bersama-sama antara tim pengabdian dan peserta pelatihan menghasilkan beberapa hal, yaitu: a) Program PKM akan lebih efektif jika dilakukan dengan pola pendampingan yang simultan; b) Media pembelajaran berbasis ICT menggunakan aplikasi Lectora Inspire efektif digunakan dalam pembelajaran; c) Pembuatan media pembelajaran berbasis ICT menggunakan aplikasi Lectora Inspire membutuhkan perencanaan yang matang dan waktu yang cukup lama. Selanjutnya, media pembelajaran berbasis ICT menggunakan aplikasi Lectora Inspire dapat digunakan oleh siswa siswa sekolah dasar baik di kelas tinggi maupun di kelas rendah.

KESIMPULAN DAN SARAN (TNR 12 point, Bold, spasi 1,5)

Berdasarkan hasil kegiatan pelatihan dapat disimpulkan bahwa kegiatan pembelajaran pada jenjang sekolah dasar dapat dilakukan melalui penggunaan media pembelajaran pembelajaran berbasis ICT menggunakan aplikasi Lectora Inspire. Antusiasme peserta yang merupakan guru-guru sekolah dasar yang ada di Kecamatan Japara Kabupaten Kuningan sangat tinggi, sehingga mereka mampu membuat dan mengembangkan media pembelajaran berbasis ICT menggunakan aplikasi Lectora Inspire di akhir pelatihan.

UCAPAN TERIMA KASIH (TNR 12 point, Bold, spasi 1,5)

Terima kasih kepada DRPM Kemenristekdikti yang telah memberikan hibah melalui skema Program Kemitraan Masyarakat (PKM), Segenap unsur pimpinan STKIP Muhammadiyah Kuningan, para pihak yang telah membantu penulisan karya tulis ilmiah ini, terutama kepada para penulis sebelumnya yang terdapat di dalam daftar pustaka dan juga reviewer dan editor dari jurnal ini, sehingga kami dapat mempublikasikan topik ini..

\section{DAFTAR PUSTAKA}

Anwariningsih, Huning Sri. 2014. Kesiapan Penggunaan ICT pada Sekolah Dasar di Daerah Rural dalam Perubahan Paradigma Pembelajaran. Seminar Nasional dan Call For Papers UNIBA.

Mas'ud, Muhammad. 2012. Membuat Multimedia Pembelajaran dengan Lectora. Yogyakarta:Shonif

Mayer, Richard. 2009. Multimedia Learning. Yogyakarta: Pustaka Pelajar 
Mendikbud. 2014. Lampiran I Peraturan Menteri Pendidikan dan Kebudayaan Nomor 58, Tahun 2014, tentang Kurikulum 2013 Sekolah Menengah Pertama/Madrasah Tsanawiyah.

Munir. 2010. Kurikulum Berbasis Teknologi Informasi dan Komunikasi. Bandung: Alfabeta

Rumidjan, Sumanto, Sukamti, \& Sugiharti. 2017. Pelatihan pembuatan media pembelajaran untuk meningkatkan kualitas pembelajaran bagi guru sekolah dasar. Abdimas Pedagogi, $1(1), 77-81$.

Sanjaya, Wina. 2010. Perencanaan dan desain sistem pembelajaran. Jakarta: Kencana Prenada Media Group.

Shalikhah, Norma Dewi. 2016. Pemanfaatan Aplikasi Lectora Inspire sebagai Media Pembelajaran Interaktif. Jurnal CAKRAWALA, Vol. XI, No. 1, Juni 2016.

Shalikhah, Norma Dewi, et al. 2017. Media Pembelajaran Interaktif Lectora Inspire sebagai Inovasi Pembelajaran. Jurnal WARTA LPM, Vol. 20, No. 1, Maret 2017: 9-16, p ISSN: 1410-9344, e ISSN: 2549-5631.

Sriyanti, I., Murniati, M. M., \& Yusuf, M. 2015. Pelatihan pembuatan media pembelajaran berbasis e-learning bagi guru SMA Srijaya Negara Palembang. Jurnal Inovasi dan Pembelajaran Fisika, 2(1), 12-18.

Surjono, Herman Dwi. 2010. Pemanfaatan teknologi informasi dan komunikasi dalam peningkatan kualitas pembelajaran. Makalah. Disajikan dalam seminar MGMP Terpadu SMP/MTs Kota Magelang.

Suradijono, S. H. R. 2004. Pembelajaran berbasis web: Suatu tinjauan dari aspek kognitif. In Lokakarya Metode Pembelajaran Berbasis Web. Departemen Teknik Penerbangan ITB, Bandung, October 1, 2004.

Sutarna, Nana dan Lutfi, Ahmad Fajri. 2019. Media Pembelajaran untuk SD menggunakan Lectora Inspire. Cirebon: Nusa Litera Inspirasi 


\section{LAMPIRAN}

Adapun indikator luaran dari program PKM ini dapat dilihat dalam Tabel 1.

Tabel 1 Indikator Luaran Program

\begin{tabular}{|c|c|c|c|}
\hline No & Target & Metode & Luaran \\
\hline 1 & $\begin{array}{lr}\text { Peningkatan pemahaman guru } \\
\text { sekolah dasar di Kecamatan Japara } \\
\text { Kabupaten Kuningan terhadap } \\
\text { Pembelajaran berbasis } \\
\text { menggunakan Lectora Inspire }\end{array}$ & $\begin{array}{l}\text { Workshop } \\
\text { brainstorming, diskusi } \\
\text { dan ceramah }\end{array}$ & $\begin{array}{lr}\text { Media } & \text { Pembelajaran } \\
\text { berbasis } & \text { ICT } \\
\text { menggunakan } & \text { Lectora } \\
\text { Inspire } & \end{array}$ \\
\hline 2 & $\begin{array}{l}\text { Peningkatan kompetensi guru sekolah } \\
\text { dasar di Kecamatan Japara } \\
\text { Kabupaten Kuningan dalam } \\
\text { pembuatan dan pengembangan } \\
\text { Media Pembelajaran berbasis ICT } \\
\text { dengan aplikasi Lectora Inspire } \\
\text { menggunakan title wizard 'Aqua'. }\end{array}$ & $\begin{array}{l}\text { Pendampingan } \\
\text { diskusi }\end{array}$ & $\begin{array}{l}\text { Media Pembelajaran } \\
\text { berbasis ICT dengan } \\
\text { aplikasi Lectora Inspire } \\
\text { menggunakan title } \\
\text { wizard 'Aqua'. }\end{array}$ \\
\hline 3 & 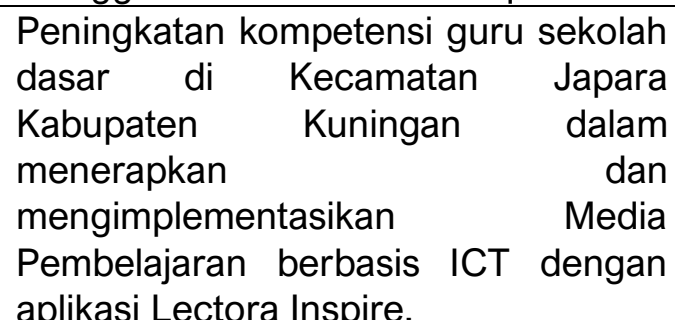 & $\begin{array}{l}\text { Pendampingan } \\
\text { kolaborasi }\end{array}$ & $\begin{array}{l}\text { Rekaman penerapan } \\
\text { dan } \\
\text { pengimplementasian } \\
\text { Media Pembelajaran } \\
\text { berbasis ICT dengan } \\
\text { aplikasi Lectora Inspire }\end{array}$ \\
\hline
\end{tabular}

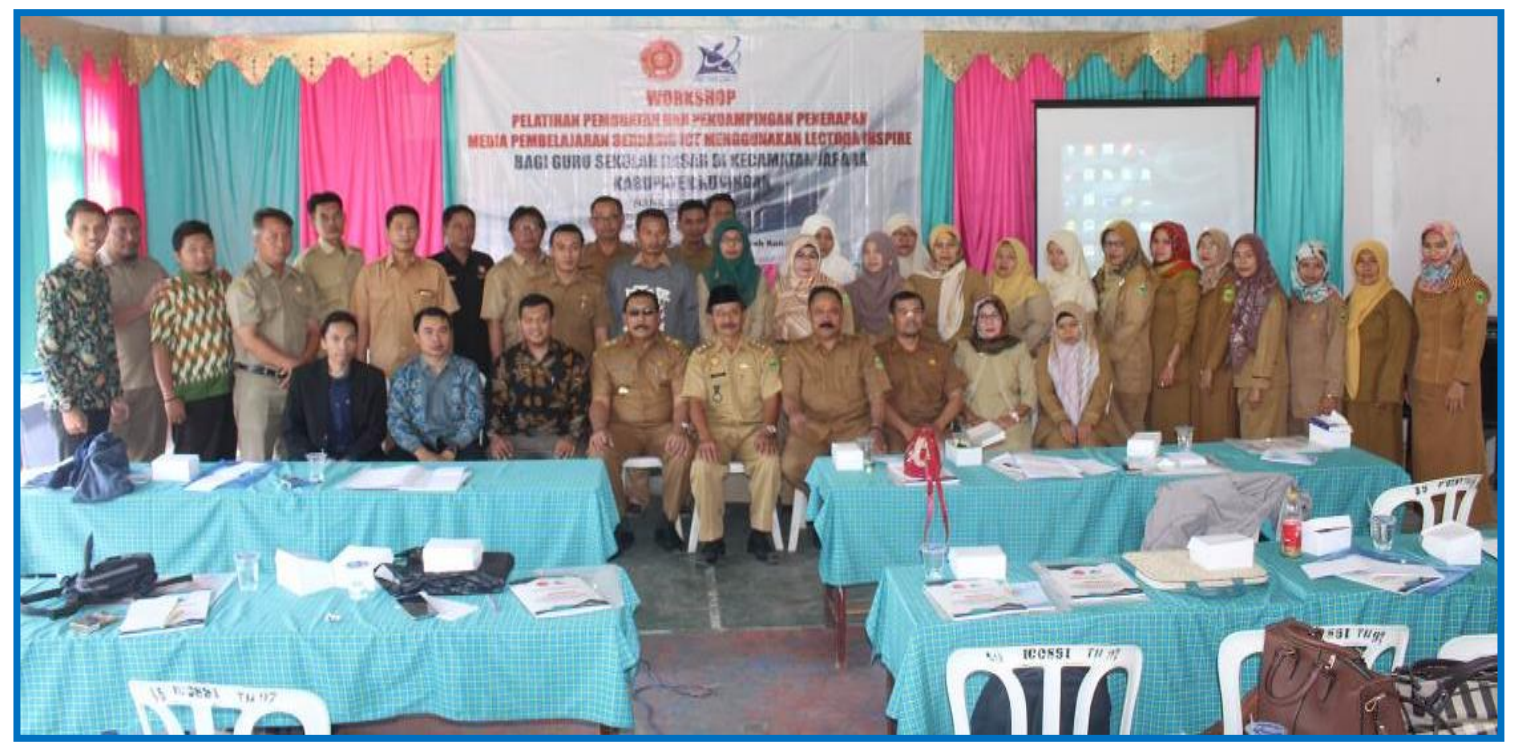

Gambar 2. Kegiatan Pelatihan Sesi 1 pembukaan kegiatan PKM 


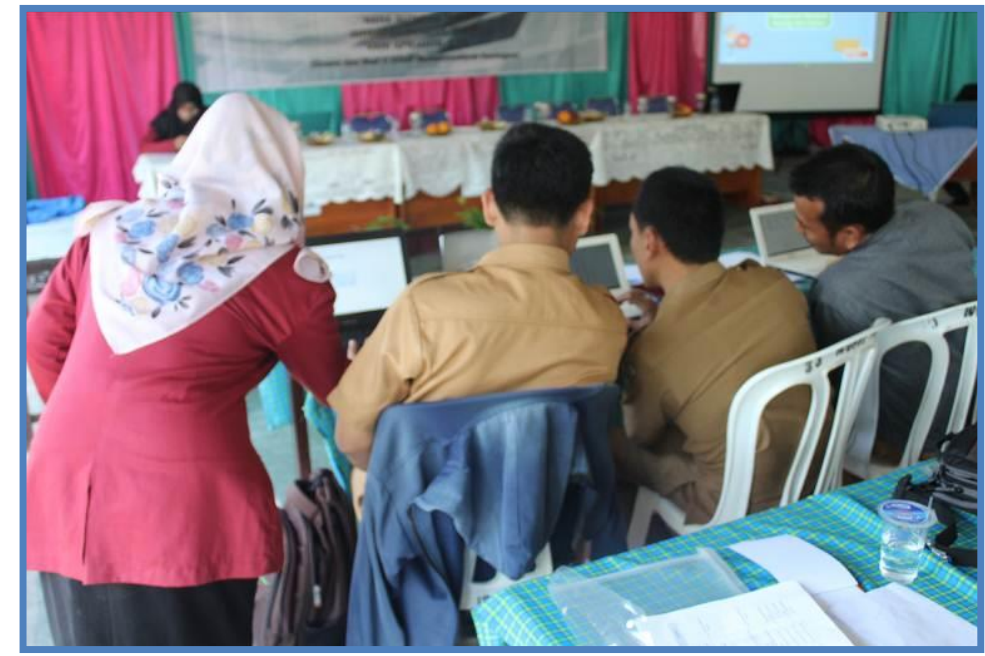

Gambar 3. Kegiatan Pelatihan Sesi 2 instalasi aplikasi

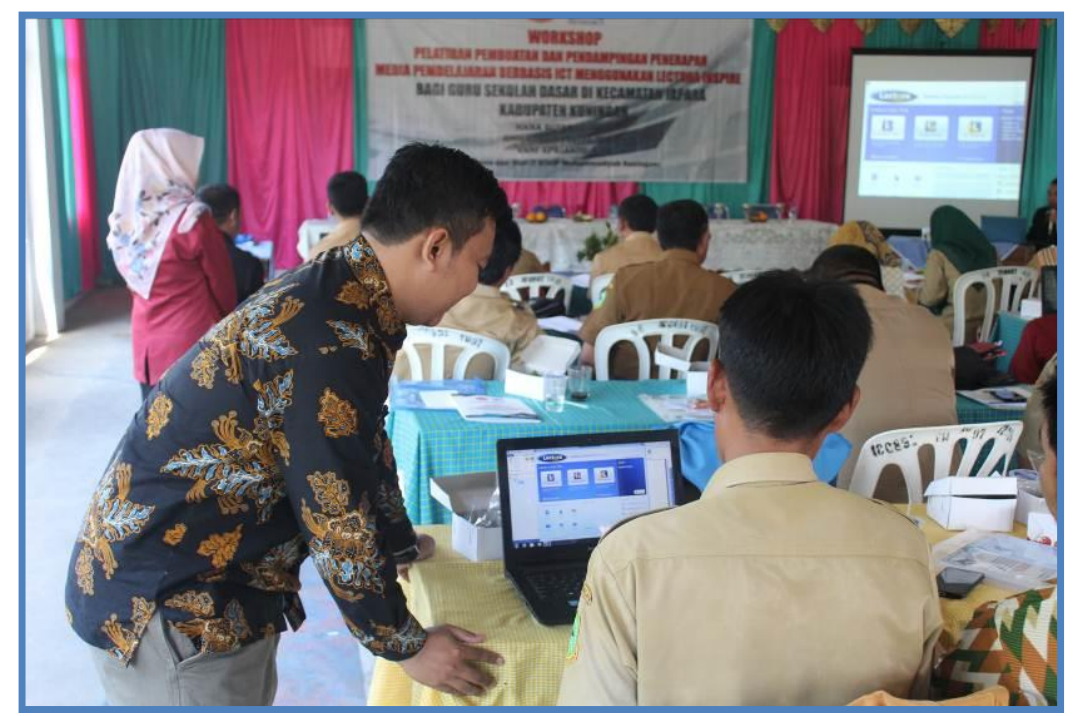

Gambar 4. Kegiatan Pelatihan Sesi 3 pembuatan media pembelajaran berbasis ICT menggunakan Lectora Inspire

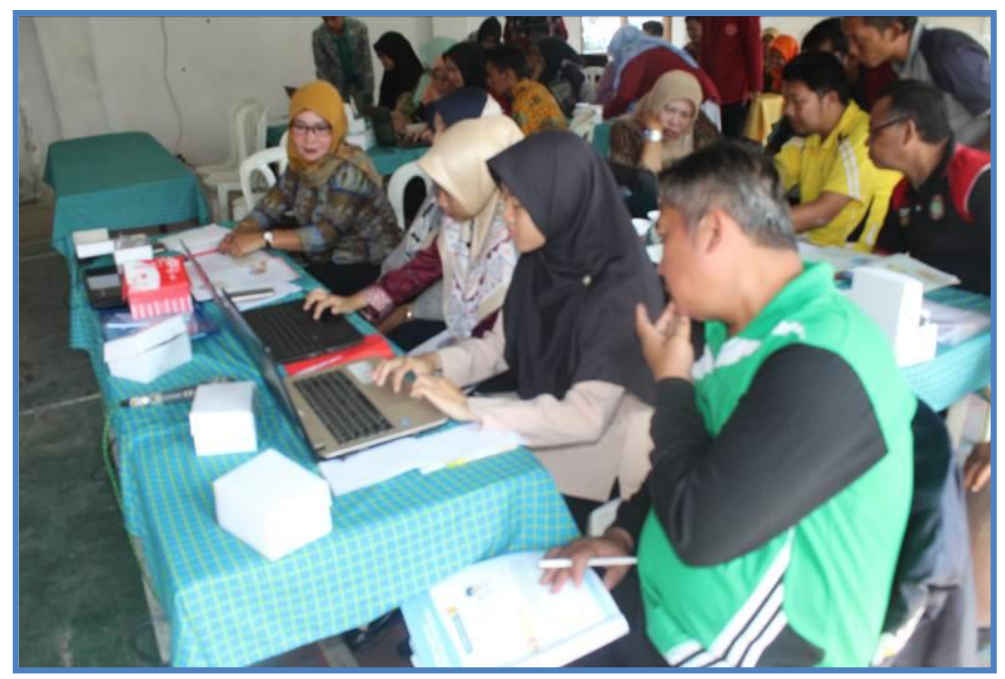

Gambar 5. Kegiatan Pelatihan Sesi 4 pembuatan media pembelajarannya 


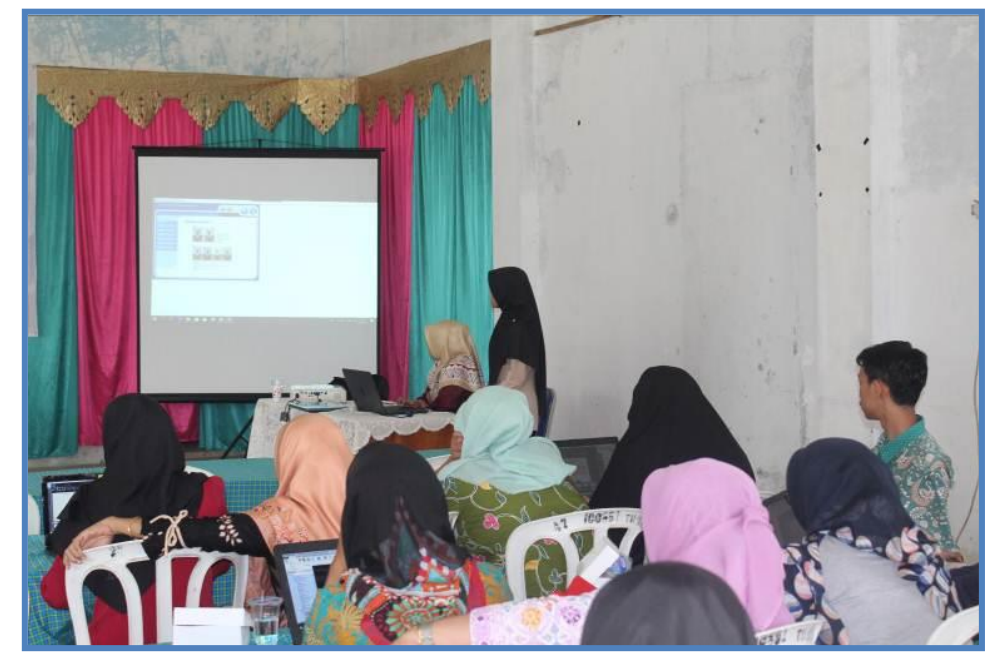

Gambar 6. Kegiatan Pelatihan Sesi 5 peserta kegiatan pelatihan mempresentasikan hasil media pembelajaran

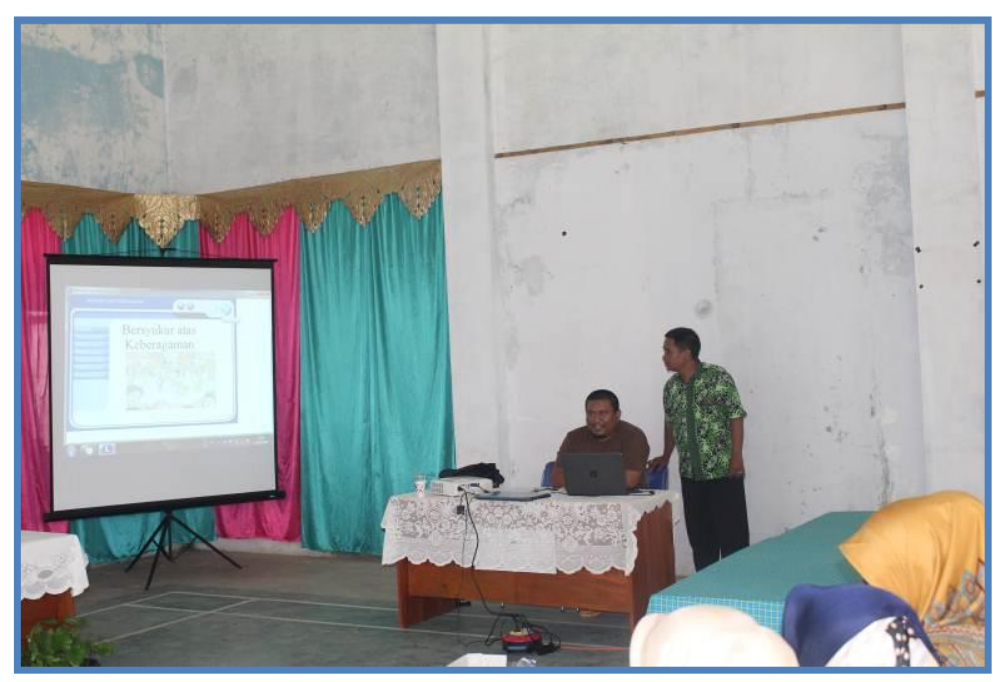

Gambar 7. Kegiatan Pelatihan Sesi 6 peserta kegiatan pelatihan mempresentasikan hasil media pembelajaran 